\title{
Geopolitical Television Drama Within and Beyond the Nordic Region
}

\author{
Pei-Sze Chow, ${ }^{\mathrm{I}}$ Anne Marit Waade, ${ }^{\mathrm{I}}$ \& Robert A. Saunders ${ }^{\mathrm{II}}$ \\ ${ }^{\text {I }}$ Department of Media Studies and Journalism, Aarhus University, Denmark \\ II Department of History, Politics, and Geography, Farmingdale State College (SUNY), USA
}

\begin{abstract}
This article presents a framework for thinking about the intersections between geopolitics and Northern European television drama by examining the contemporary Nordic Noir genre of crime drama. Nordic Noir features not only the double plot that combines sociopolitical critique with crime drama, but also a third "gaze" that engages aesthetics and territorial features that further individual series' geopolitical critique. Nordic Noir has become especially attuned to contemporary geopolitical issues specific to its setting (climate change, East-West rivalries, etc.), through which viewers engage with region-specific geopolitical codes and visions. However, what happens when Nordic geopolitical television drama series are exported and transculturally adapted to different geopolitical and cultural realities? By examining the Southeast Asian localisation of The Bridge (Viu/HBO Asia, 2018-) that transforms Nordic Noir into "tropical noir", this article critically reflects on the geopolitical power and societal engagement of the Nordic Noir template both within and beyond the Nordic region.
\end{abstract}

Keywords: Nordic Noir, geopolitics, transcultural adaptation, Bron/Broen, The Bridge, Southeast Asia

\section{Introduction}

Over the past two decades, Nordic television drama has seen a significant leap in popularity and critical attention. Driven initially by the success of screen adaptations of literary crime thrillers like Wallander (2005-) and the Millennium trilogy (2009-2010), international broadcasters and distributors have raced to create television dramas produced and set in Nordic countries, helped along by the transnational brand of Nordic Noir as an exemplar of what Janet McCabe and Kim Akass (2007) call "quality television". As such, Nordic dramatic television series - from Borgen (2010-2013) to Bron/ Broen [The Bridge] (2011-2018) to Okkupert [Occupied] (2015-) - currently serve as a model for the rest of the world. Shaped (and largely funded) by public service broadcasting traditions that are rooted in social critique, these series provide a rich reservoir of representation of how Northern Europe sees itself. With this in mind, studying the geopolitical implications of television series within and beyond Norden (literally "the

Chow, P., Waade, A. M., \& Saunders, R. A. (2020). Geopolitical television drama within and beyond the Nordic region. Nordicom Review, 41(Special Issue 1), 11-27. https://doi.org/10.2478/ nor-2020-0013 
North" - a term for the region widely used across the Nordic countries) offers the opportunity to examine not only how the region's televisual texts build lifeworlds (Gavins \& Lahey, 2016; Tischleder, 2017; Wolf, 2012), but also the role that these visually and textually produced imaginaries play in contemporary politics, society, and culture.

In this article, we focus on the critical possibilities of Nordic Noir as a genre of popular television drama that is watched and adapted around the globe. We posit that complex geopolitical themes and plots are imbricated with the genre's unique focus on weaving sociopolitical critiques (often of the Scandinavian welfare state) into the crime plot - a feature of the feted "double storytelling" tradition in Scandinavian television drama production (Redvall, 2013) - and further mediated through a third layer of critique, or a "third gaze", that foregrounds Nordic landscapes or aesthetics as an actor. Following Robert A. Saunders's (2019b) work on geopolitical television drama, it is clear that Nordic crime dramas are high-quality series that engage with world politics via imaginary scenarios, build understandings of social, geographical, and political realms, and question basic ideas of domestic versus foreign identities via their narratives. We further argue that the particular textures and contours of such geopolitically inflected Nordic Noir television has inspired new perspectives on crime television drama production far beyond Norden. In particular, to what extent can the geopolitical and critical tensions inherent in the Nordic Noir genre also speak to realities outside the Nordic region, and even beyond the European context? By examining Viu/HBO Asia's Southeast Asian The Bridge (2018-) as a transcultural adaptation from Nordic Noir to "tropical noir," we provide a critical assessment of how the dynamics between geopolitics and televisual representation function when a popular Nordic Noir television drama is localised to a radically different geographical and cultural context.

\section{Public service crime drama - from double plot to triple gaze}

Evolving out of the literary tradition of Scandinavian crime fiction, which dates back to the late 1960 s, the Nordic Noir brand emerged as a marketable category of television entertainment through a succession of Danish crime series that hit the British market in the early 2000s, notably Forbrydelsen [The Killing] (2007-2012), Borgen, and Arvingerne [The Legacy] (2014-2018), all of which were produced by the Danish public service broadcaster Danmarks Radio (DR) (Bondebjerg \& Redvall, 2015; Waade et al., 2020). Following in DR's wake, Sweden's SVT began expanding its repertoire of crime series, which had earlier found success in the German market, commissioning series such as Wallander (2008-2016) and the Danish-Swedish co-production Bron/Broen. More recently, the Norwegian (NRK), Icelandic (RÚV), and Finnish (Yle) state broadcasters have followed up by producing crime series, developing a significant audience both within and outside the Nordic region, especially via video-on-demand services like Netflix, Amazon, and Channel 4's Walter Presents.

From the perspective of geopolitical television, the characteristics of Nordic Noir are embedded in the particular public service commitments and storytelling traditions that the broadcasters within the region have refined. DR has had a leading role in this regard, with the Danish broadcaster having developed particular principles (the so-called "dogma" for television production) for high-quality television drama based on its public service commitments (Redvall, 2013). Beside adhering to the established principles 
associated with attractive visuals, quality artistic collaborations, and provision of a "good story", there is also an ambition to develop strong narratives with double plots that address ethical or social concerns. This "double plotting" is directly linked to the broadcasters' public service mandate to tell stories that challenge audiences, are important to society in general, and that other (i.e., commercial) players dare not tell (Redvall, 2019). This means that besides the immediate plotline, there is another (or underlying) narrative premise that raises difficult questions which often impugn the state, corporations, society, and even the much-touted "perfection" of the Nordic region as a whole. As such, there is a parallel to the tradition of the Scandinavian crime fiction storytelling with its consistent indictment of the problems of the Nordic welfare state. One example here is how the series Forbrydelsen aimed to show how every murderer is a human, and the notion that anyone could become a killer. The idea of double plotting is not limited to crime drama, but is also in play in other DR series such as the parliamentary drama Borgen and the historical epic 1864 (2014). Developing narratives and strong screen ideas with double plots and "one vision" has been a crucial part of DR's writers' room, in which the scriptwriter works closely together for months with the director and the producer (Redvall, 2019). The double plotline is also prevalent in the Norwegian online and real-time television youth drama Skam [Shame] (2015-2017), in which each season has a theme of relevance to not only young people, but society in general (exploring thorny questions about homosexuality, Muslim identity, gender, etc.), and told in a way that engages and challenges the viewers within and beyond Norway.

In general, when we look at the historical, institutional, and cultural conditions for crime fiction - and, later, television drama - from the Nordic region, there is an ambition to address ethical, societal, and political conditions in contemporary culture via the stories, distinguishing such fare from similar content elsewhere in Europe or North America, particularly those produced by commercial broadcasters. However, since these two forms of popular culture have become heavily consumed outside the region, a reflexive narrative layer has begun to emerge: the international fascination about anything Nordic - geography, culture, or politics - has emerged as a key marketing strategy for getting these stories made (Agger, 2020; Waade \& Jensen, 2013; Roberts, 2016). A case in point is the significant use of the region's topography and climate, like the rainy, dark November setting of Forbrydelsen, the majestic Norwegian fjords of Frikjent [Acquitted] (2015-), the glaciers and snowstorms of Ófcerd [Trapped] (2015-), the endless days of Arctic summer in Midnattssol [Midnight Sun] (2016), the iconic buildings and bridge of Bron/Broen, the skerries of Morden i Sandhamn [The Sandhamn Murders] (2010-), as well as languages, rituals, food, and music from the region (Waade, 2017; Hansen $\&$ Waade, 2017). During the last decade, we have experienced a significant growth in numbers of drama series productions within the region, caused by new online providers and an increasing demand for crime and drama series that can attract viewers, subscribers, investors, and international sales. In this context, the "Nordic aesthetics" of the series has become a significant selling point, as evidenced in Netflix's recent foray into Scandinavian-language series such as The Rain (2018-), Störst av allt [Quicksand] (2019-), and Ragnarok (2020-).

This leads to the idea that there are not only two, but rather three crucial storytelling elements characterising the genre: 1) the crime plot; 2) ethical, social, and political narrative engagement; and 3) Nordic aesthetics manifested through visual elements, 
often cinematic landscapes (Waade, 2020). The third element in this triple premise involves the viewer's gaze, linking the double plot to place and space. Recognising the distinction between the setting and the cinematic gaze in films, Martin Lefebvre (2006) explains that the latter is related to the viewer's contemplation of the landscapes and places themselves, a distinct layer of narrative and aesthetic engagement that is separate from the diegetic plot. In Nordic Noir, the cinematic gaze is in play when the Nordic elements are marked in the story, be it through depictions of landscapes; displays of fashion, design, or architecture; the use of language; performances of gender; or representations of the welfare system. This cinematic gaze emphasises the (safely) exotic and touristic qualities of the Nordic region, reaffirming the special nature of Norden as a region that has something to teach the world. Following Urry and Larsen (2011), this (cinematically abetted) tourist gaze implies a power relation - a desire to visit, appropriate, and consume.

In general, the three plot elements engage the viewer in distinct and meaningful ways: the crime plotline is a mystery and action narrative that appeals to the viewer in cognitive and emotional ways; the ethical, social, and political narrative engagement appeals to the viewer's more general worldview and societal perspectives; and, finally, the cinematic gaze refers to the viewer's aesthetic experience characterised by affect, such as contemplation, desire, and nostalgia. This triple premise encompasses different and contrasting fascinations and processes, and different viewers might mainly engage in one or two of the three. Consequently, when focusing on the pedagogical content of the Nordic Noir series, it is important to consider this triple premise as part of the storytelling process, wherein geopolitical codes and visions are conveyed not by one method of meaning-making, but a triptych comprised of the crime, an ethical or societal premise, and the cinematic gaze which features iconic sights - or sites - of Norden.

\section{Geopolitical television in and of the Nordic region}

By one reading of the discipline's historiography, we can argue that geopolitics began on the Scandinavian Peninsula. The founder of Geopolitik, Rudolf Kjellén (1864-1922), obsessed about Norway, arguing that maintaining influence over the country's mountainous geography was fundamental to the security of his native Sweden (Ó Tuathail, 2000). Kjellén went on to impact a generation of thinkers, including Karl Haushofer, whose influence on Nazi ideology is undeniable. More than a century on from Kjellén's foundational works - which described a roiling world populated with quasi-biological organisms or "super-individual creatures" (i.e., states) - geopolitics is increasingly on our minds and our screens, functioning as a "prime popular cultural and political topic in the new century" (Debrix, 2008: 9). As the French political scientist Dominique Moïsi (2016) reminds us, geopolitically inflected television reveals the "emotions of the world", particularly in times of turmoil and rapid change. Indeed, television in the new millennium - enhanced by new viewing technologies, transnational digital distribution, and ever-increasing levels of quality - is emerging as the cultural medium for exploring the world. In his analysis of post-millennial geopolitical television, Saunders (2019b: 697) describes an emergent category of serious, high-quality dramatic series that are defined by a common set of factors: 1) engagement with world politics via imaginary scenarios; 2) the building of worlds based on "situated social, geographical, 
and political understandings"; and 3) the interrogation of questions of "domestic versus foreign identities" via their narratives. From Game of Thrones (2011-2019) to Homeland (2011-2020) to House of Cards (2013-2018), big-budget Anglophone series dominate global screens, building realms of imagination that map onto our own, influencing how we see international politics and informing where one belongs in this matrix via calculated delimitations of "fictive Wes and Thems" (Gregory, 1994: 204). However, English-language series do not possess a monopoly on screening popular geopolitics via serial television. Netflix, Amazon Prime, SBS, and other transnational, on-demand content providers are increasingly populating their catalogues with non-English-language programming. While Spanish, French, and Russian series are predictably popular given the geolinguistic reach of their markets, television series from Northern Europe, and especially Nordic Noir crime dramas subtitled for global audiences, have proven extremely attractive to consumers around the globe.

As a screened scion of Scandinavian detective fiction, Nordic Noir - as a regional form of geopolitical television - possesses a particular attentiveness to its content that distinguishes it from similar fare in the US, Germany, the UK, or Italy. Rooted in a critical, leftist tradition that ultimately indicts the state or corporations through key details manifesting during the investigation (see Stougaard-Nielsen, 2017), Scandi-noir as a literary genre endowed its televisual offspring with a fecund reservoir of normative orientations and approaches to crime which have made it especially geopolitical in the current era. As Norden grapples with the challenges of globalisation, neoliberalism, transnational crime rings, migration, and climate change, noir - both in its screened and print versions - keeps apace. Recent series such as Occupied, Conspiracy of Silence (2018-), Nobel (2016-), Jordskott (2015-), Wallander, Kriger [Warrior] (2018-), and Trapped all have something to say about these issues, and more importantly, they "say" them in a Nordic way - even when using English as the medium of communication, as in the case of Viaplay's Rig 45 (2018-). Rather than aping models of geopolitical television established by American, British, or German series, Northern European programming is leading by example. Stylistically, Nordic Noir is being increasingly emulated or adapted, and in the process, the value systems inherent in the genre are bleeding through (cf. Agger, 2017; Hill \& Turnbull, 2018; Saunders, 2019a). As such, the Nordic style of dramatic television - whether in the form of rather straightforward crime dramas like Forbrydelsen or more geopolitically inclined series such as Agent Hamilton (2020-) - is making an impact around the globe and becoming a de facto extension of the so-called Nordic model rooted in good governance, social and gender equality, and the provision of welfare to its population (see Marklund, 2017). Ironically, it is through a medium that is drenched in blood and strewn with corpses that such influence is being wielded.

Few in the field of transnational television studies would argue against the notion that Nordic television series are recognised as the highest-quality with the farthest reach in the current globalised milieu and have a significant impact beyond their primarily cosmopolitan, niche audience in different nations and on different continents (Jensen, 2016). Abetted by advances in production and distribution, particularly via transnational digital distribution platforms, series like Borgen, Bron/Broen, and Shame are taking the world by storm. Recognising this state of affairs, The New York Times recently noted that "Netflix's colonization of international television continues" (Hale, 2018), highlighting the company's recent decision to fund its first production in Scandinavia, the apocalyptic 
near-future series The Rain. In using such language, it is clear that the medium of television represents a new field of power in international relations, as the images depicted, stories told, and landscapes screened help shape reality, and thus play a part in determining world politics moving forward. Second, the North - in its many forms, especially those associated with the Arctic - is increasingly prevalent in the global geopolitical imagination, especially via the tendency to engage in "spatial spectacle" or "geographic dramaturgy" (Hansen \& Waade, 2017: 89, 182), a trend that is being emulated in other national and regional television productions, from the British horror-noir Fortitude (2015-2018) to the icy Russian thriller Kholodnye berega [Cold Shores] (2019-). The most pressing issue of our time, climate change - alongside its concomitant outcomes including extreme weather events (i.e., hurricanes, heatwaves, droughts, wildfires, intense storms, etc.), extinction of species, rising sea levels, reduction in crop yields, and the displacement of peoples and disruption of their lifeways - is finding purchase in Nordic-produced popular culture, not least of which with the eco-critical, cli-fi (climate fiction) series Jordskott, Occupied, and Tunn is [Thin Ice] (2020-).

Building on Saunders's (2019b: 693) work on geopolitical television, it is important to note that different regions possess different concerns regarding "ways of seeing" and "knowing" world politics when it comes to what appears on the small screen. Just as geopolitical television programming from South Asia like Ghoul (2018) tells us about the "emotions" of the Pakistani-Indian rivalry and the Australian series Secret City (2016-2019) screens fears about China's growing influence over Canberra, so too do Nordic Noir series provide a mirror of contemporary concerns across Northern Europe. Drawing on Saunders's schema for geopolitical television which established five types of series, we see that Nordic Noir and its "near-noir" variants cover the breadth and scope of what constitutes contemporary geopolitical television. In his "exotic-irrealist" camp, we find series such as thrillers Bullets (Finland, 2018-), Beneath the Surface (Denmark, 2017-), and Moscow Noir (Sweden, 2018-). In the "parliamentary-domestic" realm, we find paradigmatic examples that include Blå ögon [Blue Eyes] (Sweden, 2014-2015) and Stella Blómkvist (Iceland, 2017-). Certainly, the much-emulated Swedish-Danish series Bron/Broen serves the ultimate "procedural-localised" category; however, more recent fare such as Sorjonen [Bordertown] (Finland, 2016-) and Wisting (Norway, 2019-) continue Norden's dominance of the detective genre. In terms of Saunders's category of "historical-revisionist" series, Nordic Noir does not fit the model particularly well beyond the eighteenth-century political crime drama Anno 1790 (one might also include the 2014 Danish war epic 1864, as it was "branded" as Nordic Noir in the UK); however, close attention to historical events that colour the present is a hallmark of the genre, from the obsession with Sweden's murky past in Wallander and Conspiracy of Silence, to the reflection on the colonisation of Sápmi in Midnight Sun. Regarding the "speculative-fantastical" type, certainly the aforementioned The Rain (Denmark/ Sweden), Occupied (Norway), and Jordskott (Sweden) are Nordic Noir exemplars, as are the recent sci-fi series Beforeigners (2019-), which examines the issue of immigration through an allegorical treatment of time travel, and Netflix's contemporary Norse mythology fantasy series Ragnarok.

However, it is perhaps more telling to explore areas where Nordic Noir series defy easy categorisation within Saunders's typology. Iceland's Hraunið [The Lava Field] (2014-), Denmark's Warrior, and the Swedish-Danish Advokaten [The Lawyer] (2018-) 
all tap into regional concerns about the growing threats that international criminal gangs pose to the tranquillity of the "North". Industrial thrillers such as Denmark's Bedrag [Follow the Money] (2016-), Finland's Karppi [Deadwind] (2018-2020), and Norway's Mammon (2018-), all speak to Norden's concerns about corruption, peak liberalism, and threats to the environment via the context of the noir thriller. Whereas, series such as the Finnish-German Arctic Circle (2018-) and Norway's Valkyrien (2017-) interrogate looming fears associated with biological contagion, as do The Rain and Fortitude. And while the concept of Nordic Noir is being stretched to its ends - and some critics argue that it has, to use a euphemism from television studies, "jumped the shark" - there is a steady stream of new series that continue to put geopolitics front and centre, focusing on threats from the climate crisis (Thin Ice) to the "new Cold War" (Agent Hamilton) to ISIS (Kalifat [Caliphate], 2020-).

As is evident, the geopolitical, social-ethical, and eco-critical elements of Nordic Noir are highly embedded in the region's democratic and cultural conditions - the genre reflects and speaks to its Nordic codes and visions of how the world "really works" (Rowley \& Weldes, 2012). However, when a Nordic Noir series is exported as a format, and further "remapped" (Forrest \& Martínez, 2015) onto other social and geopolitical contexts beyond this region, does the genre retain its socially and politically critical edge and engagement that it exerts within the Nordic region? Or does this feature of societal criticism and geopolitical engagement simply become an exotic veneer in the format within the transcultural trade, import, acquisition, and adaptation of popular Nordic crime series outside the region? And how is this negotiated in media systems and cultures that have differing levels of regulatory tolerance when it comes to the depiction and critique of local or regional politics in popular media? In the next section, we consider the evolution of the Nordic Noir genre as it travels beyond Norden and its culturally Western and geographically northern environs, examining the ways in which a particularly Nordic sensibility of enfolding socio- and geopolitical critique into television drama is transposed to a specific Southeast Asian context.

\section{From Nordic Noir to tropical noir - refracting Southeast Asia in The Bridge}

The case of the Southeast Asian localisation The Bridge demonstrates the complexities inherent in transposing the critical dimensions of the Nordic Noir genre to culturally, geographically, and media-systemically distant contexts. While an engagement with locally specific geopolitical themes is evident in this adaptation, these depictions fall short of directly addressing those issues in a critical light that would meet the criteria of contemporary Nordic Noir. This is not for lack of effort by the creative team, but rather a consequence of several practical and operational considerations: the nature of the digital delivery platform, the much broader audience group at which the series is aimed, and local regulatory restrictions. As a result, the critical edge and potential of the Nordic Noir template is rendered inert in its transition from the septrional to the tropical realm. Given the profoundly different everyday sociopolitical realities of Southeast Asia versus those in Norden, it is therefore not surprising that such tropical noir - when remapped on to a balmy, verdant space - loses (or at least blunts) its crisp, critical edge. Reflecting the trend to brand various forms of crime drama that bear 
some resemblance to Nordic Noir, but which transpose a different cultural geography on to these narratives, as a "new" type of noir (e.g., Mediterranean noir, Celtic noir, and Outback noir), we define tropical noir here as socially engaged, slow-paced police procedurals set in lush, semi-equatorial regions of the globe. ${ }^{1}$ As we discuss below, the shift from Norden (greatly defined by its comparatively corruption-free welfare state) to Southeast Asia (where decolonisation, post-imperial intrigues, and subjugation to the economic dominance of the Global North presents a host of challenges to "good governance") thus necessitates a shift of narrative focus (see, e.g., Forrest \& Martínez, 2015) alongside an aesthetic differentiation.

As discussed earlier, the broad international impact of Nordic Noir has been widely acknowledged, whether it is the global export and reception of such television dramas (Bondebjerg \& Redvall, 2015), the influence of Nordic production values (Waade \& Jensen, 2013; Jensen et al., 2016), or the adaptation of a Nordic Noir aesthetic and approach to social critique to dramas set in different geographical locales (Creeber, 2015; Hansen \& Waade, 2017; Badley et al., 2020). Travelling to or influencing the production of dramas in countries beyond Scandinavia like Germany, France, the UK, Poland, Russia, Australia, and the US, the march of Nordic television production (and its practitioners) is in full swing. While its popularity is more noticeable in European and Anglosphere territories, as described above, its impact in Asia has been fairly muted, in part due to its status as a relatively unpopular (that is, not known to mainstream audiences) genre of non-English-language drama and availability only on niche television channels. Bron/Broen is a noteworthy exception to this, being the one Nordic Noir series to have travelled to the Asian region - as a localisation. After a string of successful localisations of Bron/Broen set in Franco-British (The Tunnel, 2013-2017), US-Mexican (The Bridge, 2013-2014), and Russo-Estonian (Moct/Sild [Bridge], 2018-) contexts, the format has been adapted to a Southeast Asian context, taking root in the transnational regional space encompassing the countries of Malaysia and Singapore. This movement to a distant peripheral region is in large part due to the adaptability of its cross-border premise. Attendant themes of the original series, it seems, can be retooled to fit almost any geopolitical context that bears some similarity to the Dano-Swedish Øresund region; ${ }^{2}$ hitherto, this process has involved continuing the socially conscious slant to the police procedural genre. Despite such adaptability, it should be acknowledged that the format has not been transposed to wherever cross-border regions exist - it has so far travelled within varying groupings of territories that are geolinguistically or culturally proximate. That Bron/Broen has now been adapted in a territory much farther afield is an interesting nuance to the geopolitics of television flows, in particular the "peripheral counter-flow" (Jensen, 2016) wherein a media product from one geographically and linguistically peripheral audiovisual culture (Scandinavia) travels successfully to the "centre" (typically understood as the major Anglophone markets like the UK and US). Now, and particularly following the successes of the British-French and American-Mexican versions, the Southeast Asian adaptation might constitute an extension of this peripheral counter-flow to yet another peripheral context (via a detour through the "centre"). In the context of the transnational geopolitics of global television, this secondary flow between the (partially) Anglophone adaptations and Southeast Asian adaptation could further be explained by the fact that the region is no stranger to the "procedural-localised" category of geopolitical television that Saunders describes and, more significantly, there is the relationship of 
linguistic proximity since, as former British colonies, Malaysia and Singapore have large English-speaking populations, are already net importers of anglicised media content, and closely follow media trends in the Anglophone world.

Bron/Broen stands out as a series with a premise that is squarely centred on the linkages between crime, society, and geopolitics - one of cooperation between the police forces of two neighbouring countries to solve crimes that are committed across borders but within a region defined by cultural difference and convergence. While the DanoSwedish Øresund region serves as the setting for the Scandinavian original, much of the drama also includes representations of particular relationships and tensions within Norden, across Europe, and beyond. There is indeed something televisually seductive about a crime drama set on and near an international frontier, as the narrative affordances of border regions include challenging the very notion of a border and exploring contemporary issues like migration and transnational mobility, national and regional identities, global trade, political violence, and the sociopolitical impacts of global climate change. As Mireille Rosello and Stephen F. Wolfe (2017: 5) write: "Borders become meaningful through sensory perception and can only be legible, understandable via forms of aesthetic sensitivity that we learn as geo-political subjects". According to Rosello and Wolfe, the border becomes a necessarily aesthetic figuration that produces particular aesthetic effects and offers opportunities to reconfigure spatial, political, and social relations. Hence, their representation on popular television has the potential to afford the viewer's sensory perception of and engagement with particular social and geopolitical problems that are intertwined with border dynamics, and particularly as they relate to the viewer's own sociopolitical environment and emplacement within it.

The producers of the original series have thus capitalised on Bron/Broen as a format based on borders, the series being a piece of intellectual property now owned by the global media company Endemol Shine that shops around its unique selling points as, on the one hand, a cross-border Nordic Noir quality drama of dual nationality and, on the other hand, a reflection on regional dynamics on a broader geopolitical stage. In an elite interview, Head of Production of the Malaysian production company Double Vision and executive producer of The Bridge, Min Lim, emphasises a narrative that positions herself as a transnational cultural intermediary (Kuipers, 2012) and gatekeeper (Ettema \& Whitney, 1982) in the international border-crossing trajectory of Bron/Broen from Scandinavia to Asia. Having watched and been inspired by both the original and the Anglophone localisations, Lim subsequently negotiated the rights to produce an adaptation of the series in Southeast Asia, partnering with HBO Asia and the Hong Kong-based subscription video-on-demand platform Viu to finance the project. In this narrative, Lim's position as the producer fulfils a geopolitical function in mediating the televisual flows and counter-flows between centre and periphery, connecting television culture and audiences in this specific part of Asia to the global "cosmopolitan elite" audience that consume Nordic Noir drama. Furthermore, if, as Saunders notes, the series functions as "an imaginative, predicating, even predictive force in the cross-border relations of the countries in which it is set" (2019a: 983), then Lim's action of importing the format plays a particular role in facilitating and enacting this audiovisual (re)imagination of geopolitics in Southeast Asia.

An example of how Nordic Noir not only travels globally but also attempts to transpose its socially and politically conscious ethos to both analogous and dissimilar po- 
litical and cultural contexts, the Malaysia-Singapore localisation, The Bridge, debuted on the pan-Asian platform Viu and on HBO Asia in November 2018. Lim emphasises that the production was the first of its kind in Asia: a high-budget crime series based on a scripted format. For comparison, a typical Malaysian production would cost USD 15,000-18,000 per episode to make, while The Bridge cost around USD 100,000 per episode (personal interview with Min Lim, 4 July 2019). As befitting the aforementioned congeries of geopolitical television defined by Saunders, the imaginary world of The Bridge is based on a contemporary social, geographical, and political picture of a particular area of Southeast Asia and develops narratives and scenarios that engage with sociopolitical discourses unique to this region. Through its depiction of a collaboration between Malaysian and Singaporean police forces, the series draws on the specific historical and geopolitical relationship between Malaysia and Singapore. Once part of a single administrative entity known as Malaya during British colonial rule, and later united within the Federation of Malaya from 1963 to 1965, Malaysia and Singapore are now two separate and independent states with diverging sociopolitical trajectories. Moreover, the current bilateral relationship resembles siblings who quarrel incessantly yet who are inextricably bound together by historical, cultural, and economic ties - a fact that fuels the narrative of the series. The series situates the main criminal case within a broader regional space and imaginary somewhat similar to that of the Nordics - that is, the region comprising ASEAN (Association of Southeast Asian Nations), to which Malaysia, Singapore, and additional neighbouring countries belong.

The main storyline of The Bridge follows the efforts of officers from the fictional International Crimes Divisions in Singapore and Malaysia, represented by Serena Teo (Rebecca Lim) and Megat Jamil (Bront Palarae), in the hunt for the Truth Terrorist after a bisected body is found on the midway point of the Malaysia-Singapore Tuas Second Link. Other elements, like the nature of the denouement and the general characterisation of the main characters, remain largely similar to the Scandinavian original, where Lim plays the stereotypically uptight and rule-bound Singaporean and Palare plays to the cliché of a laid-back Malaysian and all-round disappointment of a father, much like the Martin Rohde character in Bron/Broen. Where the localisation differs more significantly is in the finer details of cultural specificity and the depiction of geopolitical imaginations specific to Southeast Asia and its particular role in the Pacific Rim and larger global economic system.

Despite the disparate geographical landscape and cultural backdrop, the Southeast Asian localisation attempts to retain the "strangeness" and "high value" markers (Lotman, 1990: 146) of the Nordic original (such as the noir-ish plotline, bold archetypes, and dramatic aesthetics). Elements of the storyline are also recalibrated to fit within "the metalingual structure of the importing culture" (Griggs, 2018: 281). The post-industrial locales of urban Copenhagen and Malmö are thus transmogrified into the urban commercial sprawl of Johor Bahru and dense, hypermodern Singapore, with a corresponding shift from an eternally dark, cold, and overcast northern European climate to an eternally sunny and oppressingly hot and humid environs of the tropics. As Nordic Noir is recalibrated to fit the equatorial settings of tropical noir, so too does its Nordic aesthetic gaze shift to a visual gaze that elicits a different geopolitical imagination. Our use of the "tropical" nomenclature signals not only oppositional difference in climate and landscape, but also conjures some of the Southeast Asian region's sociocultural specificities 
that are markedly different from the Nordic region. Where the popular imagination of the Nordic countries projects a certain "ethnic, linguistic, and cultural homogeneity" (Hilson, 2008: 148) amongst its social democratic and broadly Lutheran societies, the articulation of tropical noir in The Bridge features a Southeast Asian region that can be characterised by a multiplicity of cultures, languages, ethnicities, and religions; densely populated and urbanised cities at varying scales of development; and deeply complex geopolitical and postcolonial entanglements with each other, the former European imperial powers, and the regional hegemon China. Instead of engagement with societal conditions and problems within the frame of social-democratic politics and the Nordic welfare state system, a Southeast Asian articulation of tropical noir addresses social issues and themes within a region guided by neoliberal politics and avoidance of social welfare programmes (Schmidt, 2000), albeit to a less explicit degree due to sociopolitical conservatism and regulatory reasons, a point to which we will return below.

That cultural specificity is an important part of the DNA of the series - functioning in part as the third, aesthetic gaze in the Nordic Noir model that activates viewers' engagement with meanings evoked by place-specific visual elements - and was taken into serious consideration by the producers and writers of The Bridge. According to Lim, the writing and producing team were mindful of the need to adapt characters and narrative elements that would engender both a sense of verisimilitude for a Southeast Asian audience and a certain level of exoticism and unique difference for an international audience beyond the region, all while maintaining the original premise of a transnational police team working on a cross-border case (personal interview with Min Lim, 4 July 2019). In terms of casting, this meant an ethnically and linguistically diverse cast that reflected the spread of ethnicities in the region:

We wanted a variety of looks. [...] We were very conscious of getting people who looked like real people... Malaysia and Singapore have diverse populations - Chinese, Malay, Indian, Eurasian... we've managed to get the whole gamut. So that's kind of what we were concerned about in terms of diversity. (Lim, 2018: 58)

Further, the series was largely shot on location amidst the dense urban cityscapes and tropical junglescapes between the state of Johor, on the southern tip of the Malay Peninsula, and the island nation of Singapore. Being just one-and-a-half degrees north of the equator, the heat, high humidity, and invariably bright conditions contrast sharply with the far chillier and darker forebear of the series. Where the noir-ness comes through is via the faded grey, blue, green, and brown palette used throughout the series that bleeds the images of vibrant colours and imparts an ashen tone to the overall image, and in particular, the characters' appearance. While the vistas of natural Nordic landscapes are typically used to evoke particular effects in the viewer's experience of the drama represented on the Nordic screen, natural landscapes in The Bridge - in the form of dense evergreen rainforests and other visual representations of the tropical climate - do not necessarily materialise as the third gaze or additional narrative and aesthetic layer to the drama. Instead, the viewer's gaze rests upon the built environment (e.g., the container terminal at Johor Port and the skyscrapers of Singapore's central business district) that comments on the intertwined relationship between place, politics, and the plot - not unlike the use of urban spaces and architecture in Bron/Broen (Chow, 2016). That the shipping port and financial district are 
featured, visually and narratively, as sites of criminality and corporate malfeasance is especially distinct for the case of Malaysia and Singapore, whose economies are undergirded by entrepôt trade and globally oriented financial systems. The narrative level is thus where the series' geopolitical affordances come to the fore, weaving in plotlines about the illegal trafficking of migrant workers from the much more populous and significantly poorer Indonesia to peninsular Malaysia, or of corruption and elaborate regional money laundering schemes that involve the international financial hubs of Singapore and Hong Kong. The space in which the events in the drama take place thus engages with the existing constellation of geopolitical relationships in the region, highlighting the complex ways that social, economic, and political experiences of the different Asian nations are deeply imbricated with each other despite apparent differences in their colonial pasts, governance structures, ideological orientations, cultural traits, and contemporary socioeconomic conditions.

For instance, one of the Truth Terrorist's five "truths" foregrounds the illegal trafficking of workers and migrants from Indonesia, whose poverty has driven them to desperation, risking their lives to get to nearby Malaysia by boat to find menial employment. The physical journey plied by the Indonesian villagers depicts their bodies being laid into the recess of a small fishing boat and hidden under a dense tangle of fishing nets. Once on Malaysian soil, they are transferred into a shipping container (like lifeless commodities) which is then driven across a Malaysian highway threading through a green hinterland. Their journey is aided by the very fishing boats and shipping containers that signal the region's maritime trade network. This visual referencing creates a backdrop that reinforces the neoliberal economic and political transnationalism of Southeast Asia, where Indonesia, Malaysia, and Singapore have been part of a cross-border economic collaboration known as the Indonesia-Malaysia-Singapore Growth Triangle since the 1990s. Within this transnational framework, authorities have frequently drawn on the rhetoric of borderlessness in the service of frictionless trade policy and economic cooperation (similar to the "borderless" framework that girds the Øresund Region showcased in Bron/Broen). The establishment of this growth triangle has since triggered the movement of Indonesian migrant workers from Indonesia's Riau Islands to Johor in Malaysia across the South China Sea, prompting criminal syndicates to conduct human trafficking and people smuggling crimes along the same route (Sulaksono, 2018). The problem of people smuggling in the region is an ongoing concern, and Indonesia is one of the largest sources of migrant labour - both legal and illegal - to neighbouring countries in Asia (Nuraeny, 2017). The journey of the migrant workers from Indonesia in The Bridge thus marks the political, economic, and social processes in the making of regional space, in that - as illegally traded "goods" - they and the smugglers traverse national boundaries and spaces, circumvent state power, and - through the Truth Terrorist's and a journalist's live exposé of their situation - generate societal responses to the issue of trafficking. ${ }^{3}$ The series can thus be seen as raising a dialogue about the human dimensions, and indeed costs, of this long-running and largely under-scrutinised illegal labour flow that has for so long been rendered invisible or marginalised in the public consciousness.

Herein lies a crucial point about The Bridge: as it was produced and financed by profit-orientated enterprises for commercial viewing platforms with no involvement from either Malaysian or Singaporean public broadcasters, the producers and writers were able to build a rather unfiltered (though fictional) world in the series. This meant 
dealing with riskier yet relevant contemporary topics in the region that rarely feature in local television dramas produced by and shown on Southeast Asian public broadcasting platforms, such as domestic violence against women and the abduction of children for child labour. Like its Scandinavian predecessor, which necessarily deals with the more unsavoury aspects of regional cooperation, The Bridge represents some of the geopolitical issues facing Southeast Asia and also invites the viewer to not only imagine, but interrogate, the real and present socioeconomic and political problems in their environment. The Bridge, as geopolitical television drama, thus (at least potentially) challenges what its domestic viewers see and know about their corner of the globe.

However, this is where the limits of its critical potential end. It is worth noting that the media environments in both countries are highly regulated by the state and enact comparatively restrictive content guidelines that discourage the depiction of (political) themes or topics that may be potentially critical of state policies and institutions, or critiques of public policies related to multiculturalism and religion (Barker \& Lee, 2019). Even though The Bridge was to be shown primarily on commercial platforms, it still had to comply with local regulations as it would be shot, produced, and made available within the local media market. This is also one of the key reasons why a fictional International Crimes Division had to be created in The Bridge, as the producers did not have the artistic license to portray even fictional members of the Singapore Police Force, for instance, as inefficient. When The Bridge was shown on a Malaysian free-to-air channel operated by the Media Prima network, it was censored to exclude depictions and suggestions of violence, sex, and nudity (personal interview with Min Lim, 4 July 2019). Considering that the series - streaming on Viu, which broadcasts in 31 countries across Southeast Asia, the Indian Subcontinent, the Middle East, and sub-Saharan Africa - would reach territories that practice similarly restrictive censorship policies, The Bridge's mild sociopolitical critique would be palatable to different domestic contexts across many borders and thereby facilitate its receptiveness in different geopolitical regions.

On the one hand, the regionally specific elements described above constitute some of the adaptation's affinity with its Scandinavian original in terms of its sociopolitical engagement. Yet, on the other hand, the triple premise that we argue is characteristic of Nordic Noir struggles to materialise in the Southeast Asian adaptation, with landscape thus reverting from a position of aesthetic foregrounding of the plot (as in Nordic Noir) to a simple backgrounding of the narrative (i.e., serving as a setting to provide context). Ultimately, the series fails to engage more deeply with the severity and specificity of crimes and the geopolitical tensions within the region - both visually and narratively - being constrained on regulatory, political, and structural levels. The production abstains from realistic depictions of the criminal acts (due to the regulatory restrictions on violence and graphic images), and at no point does the fiction hint at the involvement (or failure) of the state in the issues highlighted in the drama. Nor does it seem relevant to do so, since both the Malaysian and Singapore governments adopt different - that is, almost opposite - social welfare policies from the Nordic model. That a fictional regional crime syndicate called Red Harvest - which apparently lies at the heart of the Truth Terrorist's "truths" - is mentioned, yet remains largely invisible and vaguely defined, also contributes to a lessening of what might have been substantial and specific geopolitical critique (therein echoing the anodyne tropes of mainstream, commercial 
forms of geopolitical television such as the American series The Blacklist, MacGyver, and Hawaii Five-0). Furthermore, if transnational financial crimes, fraudulent dealings of corporate billionaires, and the unethical tactics of the media were some of the narrative's criticisms, then these were somewhat ironically undermined by the highly conspicuous product placement of two digital brands BigPay and Travel360 across all episodes. ${ }^{4}$

Lim also emphasises that, due to the broad reach of Viu, the production had to also take into account an even more heterogeneous audience while also striking a balance between local cultural specificity and international, cross-cultural appeal. As Lim notes, the production's visual style and storytelling had to speak to universal values and problems, and not just appeal to Malaysian and Singaporean audiences (personal interview with Min Lim, 4 July 2019). As such, save for the linguistic markers of English and Malay used in the dialogue and the multi-ethnic, pan-Asian representation of the cast, the production design is culturally neutral, or sometimes even incongruent with the everyday geographical realities of the region (for instance, the characters wear multiple layers of clothes outdoors in a tropical climate that averages 30 degrees Celsius throughout the year), while many of the social problems depicted in the series remain acultural and their relationship to specific institutional influence or policy are undefined. This difficult negotiation between the universal and the particular results in a conflicted process of worldbuilding in The Bridge that locates the narrative in a clearly Malaysian-Singaporean geographical setting. Yet, it steps back from a more specific and meaningful critique of domestic politics within the two countries, Malaysian-Singaporean bilateral relations, and larger issues related to the ASEAN region, which is marked by great diversity (unlike the Nordics who are united by a high degree of cultural and political similarity) and a more conservative political sensitivity to discussions of nationhood, ethnicity, and religion. Such a cacophonous, transnational public sphere indubitably contributes to the difficulty faced by The Bridge's producers and writers to include particular topics that might allow for deeper conversations about the region's geopolitical complexities and shared or divergent geopolitical codes and visions, not to mention the diverse legacy of British, Dutch, French, Spanish, and American imperialisms. Thus, where Bron/Broen employs a tripartite strategy (through focusing on the interwoven crime plot, social and political conditions, and aesthetic cinematic gaze of the region) in articulating specific critiques of the Nordic welfare state and particular geopolitical characteristics of Norden, its Southeast Asian adaptation can only adopt a perfunctory stance towards such interrogations of culture, history, and society.

\section{Conclusion}

Employing an extra-regional case study of Viu/HBO Asia's The Bridge, we have argued, in concert with other articles in this special issue, that the case for reading Nordic Noir television series through a geopolitical lens arises from the genre's roots - both literary and audiovisual - in interweaving critiques of the welfare state and contemporary sociopolitical conditions into the central crime plot. By bringing an analytical approach and a recognition of the rise of geopolitical television into dialogue with the double-plot feature (further enriched by a third dimension of the aesthetic gaze), we have demonstrated that not only does Nordic Noir travel, it changes its constitution during the journey. As we have shown, the Southeast Asian The Bridge is a case study of how geopolitics 
intersects with fiction and is thus infused into the drama; this is particularly salient with regards to the complex negotiation of national and regional identity in an interconnected world where real and imagined borders are too easily trespassed. In terms of production values and the transnational appeal of the genre, we have also argued in this article that the high degree of mobility and apparent translatability of Nordic Noir - especially via the global licensing trajectories of Bron/Broen - to other and culturally distinct regions can be attributed to the genre's unique selling point of the infusion of crime narratives, sociopolitical critique, and regional geopolitical realities and imaginaries in one package. However, this translatability is conflicted. In the context of the Southeast Asian localisation of The Bridge, the metamorphosis of Nordic Noir into tropical noir has potentially engendered a larger appetite for high-quality and bigger-budget crime television drama in the region (the second season of The Bridge premiered online in June 2020), while importing some aspects of a Nordic sensibility to mediating socio- and geopolitics via popular television culture. Yet, the Southeast Asian case also demonstrates that there are conflicting ideas and objectives in the series: the popular, commercial, aesthetic, and contextual production elements obstruct, or at least contradict, the narrative's attempts to enact geopolitical commentary and societal criticism. The triple premise and critical edge in Nordic Noir as we have explained in this article thus becomes muted and undermined in the face of the actual political and commercial conditions in the Southeast Asian region, where a certain sociopolitical conservatism and the realities of censorship demand an unsharpening of this critical edge in the narrative. Thus, when Nordic Noir series are adapted and exported to places and cultures outside the Nordic region, this conflict can appear even clearer.

\section{Notes}

1. Beyond Southeast Asia, other potential locales might include the Caribbean Basin, parts of Latin America, southern India, sub-Saharan Africa, and Oceania.

2. That is, a cross-border region where the two countries bordering each other have a close geopolitical relationship based on sociocultural, political-systemic similarities and yet maintain particular differences that form the basis of a degree of friendly rivalry.

3. The US-Mexico and UK-France renditions of the series similarly focused on the (illegal) routes of migrant labour, refugees, and trade across shared borders as a key geopolitical theme.

4. BigPay is an e-wallet service and Travel360 is an online travel platform. Both are subsidiaries of AirAsia, a major low-cost airline based in Malaysia and owned by Tony Fernandez, one of Malaysia's 50 richest people, according to Forbes.

\section{References}

Agger, G. (2017). Geopolitical location and plot in The Night Manager. Journal of Scandinavian Cinema, 7(1), 27-42. https://doi.org/10.1386/jsca.7.1.27_1

Agger, G. (2020). The golden age: Danish public service drama series 1995-2015. In A. M. Waade, E. N. Redvall, \& P. M. Jensen (Eds.), Danish television drama: Global lessons from a small nation. New York: Palgrave Macmillan.

Badley, L., Nestingen, A., \& Seppälä, J. (Eds.). (2020). Nordic Noir, adaptation, appropriation. New York: Palgrave Macmillan. https://www.doi.org/10.1007/978-3-030-38658-0

Barker, T., \& Lee, Y. B. (2019). Creating within constraints: Creative industries policy in Malaysia. In L. Lim, \& H.-K. Lee (Eds.), Routledge handbook of cultural and creative industries in Asia (pp. 13-26). London: Routledge. https://doi.org/10.4324/9781315660509

Bondebjerg, I., \& Redvall, E. N. (2015). Breaking borders: The international success of Danish television drama. In I. Bondebjerg, E. N. Redvall, \& A. Higson (Eds.), European cinema and television: Cultural policy and everyday life (pp. 214-239). Basingstoke: Palgrave Macmillan. https://www.doi. org/10.1057/9781137356888 
Chow, P.-S. (2016). Traversing the Øresund: The transnational urban region in Bron/Broen. In J. Andersson, \& L. Webb (Eds.), Global cinematic cities: New landscapes of film and media (pp. 36-58). New York: Wallflower Press.

Creeber, G. (2015). Killing us softly: Investigating the aesthetics, philosophy and influence of Nordic Noir television. The Journal of Popular Television, 3(1), 21-35. https://doi.org/10.1386/jptv.3.1.21_1

Debrix, F. (2008). Tabloid terror: War, culture, and geopolitics. New York: Routledge.

Ettema, J. S., \& Whitney, D. C. (Eds.). (1982). Individuals in mass media organizations: Creativity and constraint. Beverly Hills: Sage Publications.

Forrest, J., \& Martínez, S. (2015). Remapping socio-cultural specificity in the American remake of The Bridge. Continuum, 29(5), 718-730. https://doi.org/10.1080/10304312.2015.1068725

Gavins, J., \& Lahey, E. (Eds.). (2016). World building: Discourse in the mind. London: Bloomsbury.

Gregory, D. (1994). Geographical imaginations. Cambridge, Massachusetts: Blackwell.

Griggs, Y. (2018). Reconfiguring the Nordic Noir brand: Nordic Noir TV crime drama as remake. In D. Cutchins, K. Krebs, \& E. Voigts (Eds.), The Routledge companion to adaptation (pp. 278-286). London: Routledge. https://doi.org/10.4324/9781315690254

Hale, M. (2018, May 3). Nordic dramas keep streaming into America. New York Times, C6.

Hansen, K. T., \& Waade, A. M. (2017). Locating Nordic Noir: From Beck to The Bridge. Basingstoke: Palgrave. https://www.doi.org/10.1007/978-3-319-59815-4

Hill, A., \& Turnbull, S. (2018). Nordic Noir. In N. Rafter, \& M. Brown (Eds.), The Oxford encyclopedia of crime, media, and popular culture (pp. 660-675). Oxford University Press. https://www.doi.org/10.1093/ acref/9780190494674.001.0001

Hilson, M. (2008). The Nordic model: Scandinavia since 1945. London: Reaktion Books.

Jensen, P. M. (2016). Global impact of Danish drama series: A peripheral, non-commercial creative counterflow. Kosmorama, 263. http://www.kosmorama.org/ServiceMenu/05-English/Articles/Global-Impactof-Danish-Drama-Series.aspx

Jensen, P. M., Nielsen, J. I., \& Waade, A. M. (2016). When public service drama travels: The internationalization of Danish television drama and the associated production funding models. The Journal of Popular Television, 4(1), 91-108. https://doi.org/10.1386/jptv.4.1.91_1

Kuipers, G. (2012). The cosmopolitan tribe of television buyers: Professional ethos, personal taste and cosmopolitan capital in transnational cultural mediation. European Journal of Cultural Studies, 15(5), 581-603. https://doi.org/10.1177/1367549412445760

Lefebvre, M. (2006). Between setting and landscape in the cinema. In M. Lefebvre (Ed.), Landscape and film (pp. 19-60). London: Routledge. https://doi.org/10.4324/9780203959404

Lim, M. (2018, November 28). Bridge the gaps. ContentAsia, 7, 54-58. https://issuu.com/contentasia/docs/ issueseven 2018

Lotman, Y. (1990). Universe of the mind: A semiotic theory of culture (A. Shukman, Trans.). Indianapolis: Indiana University Press.

Marklund, C. (2017). The Nordic model on the global market of ideas: The welfare state as Scandinavia's best brand. Geopolitics, 22(3), 623-639. https://doi.org/10.1080/14650045.2016.1251906

McCabe, J., \& Akass, K. (Eds.). (2007). Quality TV: Contemporary American television and beyond. London: IB Tauris.

Moïsi, D. (2016). La géopolitique des séries ou le triomphe de la peur [The geopolitics of series or the triumph of fear]. Paris: Stock.

Nuraeny, H. (2017). Trafficking of migrant workers in Indonesia: A legal enforcement and economic perspective of prevention and protection efforts. European Research Studies Journal, 20(4B), 16-26. https:// www.ersj.eu/dmdocuments/2017-xx-4-b-2.pdf

Ó Tuathail, G. (2000). Critical geopolitics: The politics of writing global space. Abingdon, UK: Taylor \& Francis.

Redvall, E. N. (2013): Writing and producing television drama in Denmark: From The Kingdom to The Killing. Basingstoke: Palgrave Macmillan. https://www.doi.org/10.1057/9781137288417

Redvall, E. N. (2019). The concept of 'double storytelling' in Danish public service TV drama production. In S. Maras (Ed.), Ethics in screenwriting: New perspectives. Baingstoke: Palgrave Macmillan. https:// www.doi.org/10.1057/978-1-137-54493-3

Roberts, L. (2016). Landscapes in the frame: Exploring the hinterlands of the British procedural drama. New Review of Film and Television Studies, 14(3), 364-385. https://doi.org/10.1080/17400309.2016.1189712

Rosello, M., \& Wolfe, S. F. (2017). Introduction. In J. Schimanski, \& S. Wolfe (Eds.), Border aesthetics: Concepts and intersections (pp. 1-25). New York: Berghahn.

Rowley, C., \& Weldes. J. (2012). The evolution of international security studies and the everyday: Suggestions from the Buffyverse. Security Dialogue, 43(6), 513-530. https://doi.org/10.1177/0967010612463490 
Saunders, R. A. (2019a). Geopolitical television at the (b)order: Liminality, global politics, and world-building in The Bridge. Social \& Cultural Geography, 20(7), 981-1003. https://doi.org/10.1080/14649365.20 17.1404122

Saunders, R. A. (2019b). Small screen IR: A tentative typology of geopolitical television. Geopolitics, 24(3), 691-727. https://doi.org/10.1080/14650045.2017.1389719

Schmidt, J. D. (2000). Neoliberal globalization, social welfare and trade unions in Southeast Asia. In B. K. Gills (Ed.), Globalization and the politics of resistance (pp. 220-240). Basingstoke: Palgrave Macmillan. https://www.doi.org/10.1057/9780230519176

Stougaard-Nielsen, J. (2017). Scandinavian crime fiction. New York: Bloomsbury.

Sulaksono, E. (2018). The patterns of human trafficking on Indonesian migrant workers: Case study of Riau Islands and Johor border crossing. MASYARAKAT: Jurnal Sosiologi, 23(2), 167-186. https://doi. org/10.7454/mjs.v23i2.6562

Tischleder, B. B. (2017). Thickening seriality: A chronotopic view of world building in contemporary television narrative. The Velvet Light Trap, 79, 120-125.

Urry, J., \& Larsen, J. (2011). The Tourist Gaze 3.0. London: SAGE Publications.

Waade, A. M. (2017). Melancholy in Nordic Noir: Characters, landscapes, light and music in The Killing. Critical Studies in Television, 12(4), 380-394. https://doi.org/10.1177/1749602017729629

Waade, A. M. (2020). Arctic noir on screen: Midnight Sun (2016-) as a mix of geopolitical criticism and spectacular, mythical landscapes. In L. Badley, A. Nestingen, \& J. Seppälä (Eds.), Nordic Noir, adaptation, appropriation. New York: Palgrave Macmillan. https://www.doi.org/10.1007/978-3-030-38658-0

Waade, A. M., \& Jensen, P. M. (2013). Nordic Noir production values: The Killing and The Bridge. Akademisk Kvarter: Tidsskrift for Humanistisk Forskning, 7, 189-201. http://www.akademiskkvarter.hum.aau.dk/ pdf/vol7/13a_AWaadePMJensen_NordicNoir.pdf

Waade, A. M., Redvall E. N., \& Jensen, P. M. (2020). Danish television drama: Global lessons from a small nation. New York: Palgrave Macmillan.

Wolf, M. J. P. (2012). Building imaginary worlds: The theory and history of subcreation. New York: Routledge.

Copyright: (C) 2020 The Author(s) and Nordicom. This is an Open Access article distributed under the terms of the Creative Commons Attribution 4.0 International License (CC BY-NC-ND 4.0). 